\title{
23 Developments in Adaptation to Salinity at the Crop Level
}

\author{
Theo Elzenga, Edward G. Barrett-Lennard, \\ and Redouane Choukr-Allah
}

In the ten chapters of this section, we focus on alternative crops adapted to saline environments and on the responses of plants to salinity. The first chapter (Jovanović and Radović 2021) emphasizes the mechanisms that enable the salt-tolerant plant to survive and even thrive and produce in saline environments that are fatal or severely inhibitory to salt-sensitive plants. The presence of high levels of $\mathrm{NaCl}$ in the root zone has two major effects on plants. A direct osmotic effect, or physiological drought, reducing the uptake of water by the plants, and a toxic effect caused mainly by the replacement of $\mathrm{K}^{+}$by $\mathrm{Na}^{+}$in the cytoplasm resulting in inhibition of a multitude of cellular processes (Munns 2002; Cuin et al. 2009). Typical adaptations to soil salinity in specialized, halophytic plant species are the more efficient use of water and the accumulation of $\mathrm{NaCl}$ in the vacuole, making use of $\mathrm{Na}^{+}$as a 'cheap' osmoticum, balancing the osmotic potential in the soil with $\mathrm{NaCl}$, rather than by synthesizing metabolically expensive small molecular weight organic compounds (Greenway and Munns 1980); also the compartmentalization of $\mathrm{NaCl}$ keeps it away from the cytoplasm and sensitive enzyme systems (Flowers 1972; Greenway and Osmond 1972). Plant species from saline environments are often also capable of getting rid of excess $\mathrm{NaCl}$, using salt glands (Marcum 1999).

The domestication of halophytic species and their use in agriculture has been tested by several authors to replace or supplement the vegetation of saline rangelands (Norman et al. 2013). For example, pioneering research by Clive Malcolm and colleagues in Western Australia showed that the revegetation of saline habitats with halophytic forage shrubs (Atriplex spp.) was profitable and provided many additional benefits (see citations in Barrett-Lennard and Norman 2021); the Western Australian technology is now being applied in other parts of Australia and Pakistan (Barson and Barrett-Lennard 1995; Qureshi and Barrett-Lennard 1998).

In non-salt tolerant ('glycophytic') plant species, exposure to salinity often induces a reduction in $\mathrm{Na}^{+}$uptake in the roots, activating 'reflux' transporter systems in the root, thereby decreasing the amount of $\mathrm{Na}^{+}$reaching the leaves (Roy and Tester, 2013); the salt that does enter the xylem stream accumulates in the older leaves and the early senescence of these leaves can help to protect the younger still actively growing parts of the plant and the decrease in leaf area reduces water uptake. True salinity-adapted plant species (halophytes) typically show a growth rate increase at 
moderate salinity levels, whereas glycophytic species tend to have a strong reduction in growth at similar salt concentrations (Flowers and Colmer 2008).

Why is agriculture under saline conditions so difficult? The answer lies principally in the origin of most of our crop plants. In adopting plants that were originally gathered in nature for controlled cultivation under farmers' care, the selection favored plant species that were fast-growing, performed well in the absence of other competition and disturbed soil, did not have extensive defense traits, such as thorns or toxins, and produced many seeds. Although all these traits would have been attractive to early farming communities, they can also be considered the root cause of many of the problems that modern agriculture is now facing. The traits selected for 'tick all the boxes' of plants are categorized as ruderals (Grime 2001), the typical pioneer plants, often annuals or short-lived perennials of disturbed ecosystems. This category of plants invests relatively little resources into pathogen resistance and, as recent studies show, also may have antagonistic relations with soil and rhizosphere micro-organisms (Karol et al. 2010). In contrast, most perennial plant species invest in defense and competitiveness and in a mutualistic relation with the microbiome of the root zone. Many of the traits that enable these plants to tolerate stress, optimize resource utilization, and resist pathogens can be partly attributed to their symbiotic relationship with micro-organisms. On the other hand, the species that have been selected as our crop plants encourage antagonistic micro-organisms to thrive in the root zone, leading to the accumulation of pathogens and competing soil micro-organisms. Breeding programs have, unknowingly, further reduced the potential of plants to attract so-called plant growth-stimulating bacteria or fungi (Pérez- Jaramillo et al. 2015).

In the chapters of this section (Chapters 25, 26, 27, 28, 29), we have also reviewed the successes and difficulties that breeders and plant physiologists have encountered in trying to select for and use salt--tolerant plants in breeding programs. Most selection programs have consciously or unconsciously, been biased toward plant traits that made our agriculture more dependent on farming practices that aimed to control and optimize growth conditions (e.g. use of irrigation, fertilizers, herbicides, and pesticides). They have also reduced the capacity of our crop plants to use the services of natural allies; this has triggered new research programs on the role of symbiotic micro-organisms in stress resistance (Chapters 32, 33). The predicted increase in extreme weather events, short periods of heavy precipitation and prolonged periods of drought during the growing season, has made us aware that relying on full control of growth conditions is untenable and that our crops should be based on plant varieties that are more robust, that can fend for themselves better, and depend less on chemical means for keeping them healthy (Chapters 30, 31).

Let's look at a number of potential answers to the question how to make our crops more salt-resistant. The first is the breeding of varieties of crops that are considered glycophytic, still possessing some of the traits that, in combination, could yield very hardy varieties (Zaki 2011). For other glycophytic species, the presence of wild sister species with desirable salinity tolerance traits could be exploited by backcrossing and selecting for combinations of stress-tolerance and elite yield traits (Brozynska et al. 2015; Mickelbart et al. 2015). This approach has been adopted by researchers looking for genes for salt tolerance in grasses allied to commercial wheat (Colmer et al. 2005). 
We could also turn to nature and adopt plant species that are naturally growing in a saline environment but have not been adapted at a large scale for agricultural purposes. Most of the saline agriculture crops have only recently been entered into breeding and selection programs, although several studies have been done on what we can consider landraces, many of the traits associated with elite varieties have not been systematically studied yet. In our traditional crop plants, the elite varieties have been optimized for growth parameters such as water and nutrient use efficiency, pathogen resistance and yield, market traits, such as ability to keep in storage, and consumer traits, such as nutritional value, taste, smell, and visual appeal. For the novel saline farming crops, most of the optimization in extensive breeding programs still has to be done. Studies aimed at filling this gap can be found in Chapters 28, 29,30 , and 31 .

The last two chapters in this section of the book (Jovanović and Radović 2021; Munikumar et al. 2021) explore the potential for using plant growth-promoting bacteria of fungi to improve stress tolerance. These studies are based on the hypothesis that the symbiosis between a plant and specific micro-organisms can strongly affect a plant's resistance to abiotic stress. Isolating microbial symbionts from plants that grow naturally under particular abiotic stress conditions and exposing (or infecting) crop plants with these isolates may improve the stress resistance of the crop plant that hosts the micro-organism.

\section{REFERENCES}

Barrett-Lennard EG and Norman H (2021) Agriculture in salinizing landscapes in southern Australia: Selected research 'snapshots'. In: Future of Sustainable Agriculture in Saline Environments. Routledge.

Barson M and Barrett-Lennard EG (1995) Productive use and rehabilitation of Australia's saline lands. Australian Journal of Soil and Water Conservation 8, 33-37.

Brozynska M, Furtado A, and Henry RJ (2015) Genomics of crop wild relatives: Expanding the gene pool for crop improvement. Plant Biotechnology Journal 14, 1070-1085. doi.org/10.1111/pbi.12454

Colmer TD, Munns R, and Flowers TJ (2005) Improving salt tolerance of wheat and barley: Future prospects. Australian Journal of Experimental Agriculture 45, 1425-1443.

Cuin TA, Tian Y, Betts SA, Chalmandrier R, and Shabala S (2009) Ionic relations and osmotic adjustment in durum and bread wheat under saline conditions. Functional Plant Biology 36, 1110-1119.

Flowers TJ (1972) The effect of sodium chloride on enzyme activities from four halophyte species of Chenopodiaceae. Phytochemistry 11, 1881-1886.

Flowers TJ and Colmer TD (2008) Salinity tolerance in halophytes. New Phytologist 179, 945-963.

Greenway H and Munns R (1980) Mechanisms of salt tolerance in nonhalophytes. Annual Review of Plant Physiology 31, 149-190.

Greenway H and Osmond CB (1972) Salt responses of enzymes from species differing in salt tolerance. Plant Physiology 49, 256-259.

Grime, JP (2001) Plant strategies, vegetation processes and ecosystem properties. (2nd edn) Wiley and Sons. p 417.

Jovanović Z and Radović S (2021) Plant growth promoting bacteria as an alternative strategy for the amelioration of salt stress effects in plants. In Future of Sustainable Agriculture in Saline Environments. Routledge. 
Kardol P, Bezemer TM, and van der Putten WH (2006) Temporal variation in plant-soil feedback controls succession. Ecology Letters 9 doi: org/10.1111/j.1461-0248.2006.00953.x

Marcum KB (1999) Salinity tolerance mechanisms of grasses in the subfamily Chloridoideae. Crop Science 39, 1153-1160.

Mickelbart MV, Hasegawa PM, and Bailey- Serres J (2015) Genetic mechanisms of abiotic stress tolerance that translate to crop yield stability. Nature Reviews Genetics 16, 237-251.

Munns R (2002) Comparative physiology of salt and water stress. Plant, Cell and Environment 25, 239-250.

Munikumar S, Nataraja KN, and Elzenga JTM (2021) Tolerance to environmental stresses: Do fungal endophytes mediate plasticity in Solanum dulcamara? In Future of Sustainable Agriculture in Saline Environments. Routledge.

Norman HC, Masters DG, and Barrett-Lennard EG (2013) Halophytes as forages in saline landscapes: Interactions between plant genotype and environment change their feeding value to ruminants. Environmental and Experimental Botany 92, 96-109.

Pérez- Jaramillo JE, Mendes R, and Raaijmakers, JM (2015) Impact of plant domestication on rhizosphere microbiome assembly and functions. Plant Molecular Biology 90, 635-644. DOI: 10.1007/s11103-015-0337-7

Qureshi RH and Barrett-Lennard EG (1998) Saline Agriculture for Irrigated Land in Pakistan: A Handbook. Monograph No. 50, Australian Centre for International Agricultural Research, Canberra, p 142.

Roy SJ and Tester M (2013) Increasing slat tolerance of crops. In: Sustainable Food Production. Christou P, Savin R, Costa-Pierce BA, Misztal I, Whitelaw CBA Eds. Springer. DOI: https://doi-org.proxy-ub.rug.nl/10.1007/978-1-4614-5797-8_429

Zaki F (2011) The determinants of salinity tolerance in maize (Zea mays L.) PhD Thesis University of Groningen, p 226. http://hdl.handle.net/11370/ae616bc6-de6d-442c-8f200318fcaa63c0 